\title{
Pembatasan Kebebasan Beragama dalam Darurat Kesehatan Virus Korona di Indonesia: Perspektif HAM dan Islam
}

\author{
Adam Muhshi * dan Radian Salman ** \\ adammuhshi.fh@unej.ac.id \\ "Universitas Jember \\ *Universitas Airlangga
}

\begin{abstract}
Keywords: $\quad$ Abstract
Restrictions on This paper will examine the restrictions imposed by the Indonesian government on Religious Freedom; religious activities carried out together in places of worship during the covid-19 pandemic. Corona Virus; $\quad$ These restrictions in recent times have even reached the level of closing places of worship. health emergency; This restriction was carried out by the government with the aim of preventing the spread Human rights; of the corona virus. However, in practice, the level of citizen compliance with these Islam. restrictions is still relatively low. The question that then arises is whether restrictions on religious activities carried out together in places of worship during a pandemic (health emergency) can be justified juridically. Departing from this problem, this article will try to analyze whether or not restrictions on religious activities are correct from the point of view of human rights and Islam. The answer to this question shows that the limitation of religious activities carried out jointly in places of worship in a health emergency finds its justification both in the perspective of human rights and in the perspective of Islamic law.
\end{abstract}

Kata Kunci: Pembatasan Kebebasan Beragama; Virus Korona; Darurat Kesehatan; HAM; Islam.

\begin{abstract}
Abstrak
Paper ini akan mengkaji pembatasan yang dilakukan pemerintah Indonesia terhadap kegiatan keagamaan yang dilaksanakan secara bersama-sama di tempat ibadah pada masa pandemi covid-19. Pembatasan tersebut dalam beberapa waktu terakhir bahkan sampai pada level penutupan tempat ibadah. Pembatasan tersebut dilakukan oleh Pemerintah dengan tujuan untuk mencegah semakin meluasnya penularan virus korona. Namun dalam prakteknya, tingkat kepatuhan warga terhadap pembatasan tersebut masih relatif rendah. Pertanyaan yang kemudian muncul adalah apakah pembatasan terhadap kegiatan kegamaan yang dilakukan secara bersama-sama di tempat ibadah pada masa pandemi (darurat kesehatan) dapat dibenarkan secara yuridis. Berangkat dari persoalan tersebut, artikel ini akan mencoba untuk menganalisis tentang benar tidaknya pembatasan terhadap kegiatan keagamaan dalam sudut pandang HAM dan Islam. Jawaban terhadap persoalan tersebut menunjukkan bahwa pembatasan kegiatan kegamaan yang dilakukan secara bersama-sama di tempat ibadah dalam kondisi darurat kesehatan menemukan justifikasinya baik dalam perspektif HAM maupun dalam perspektif hukum Islam.
\end{abstract}

Copyright ( 2021 Adam Muhshi dan Radian Salman. (cc)(i) Published in Media Iuris. Published by Universitas Airlangga, Magister Ilmu Hukum.

\section{Pendahuluan}

Corona virus disease 2019 (covid-19) yang terdeteksi muncul kali pertama di Wuhan pada penghujung Desember 2019 kemudian menyebar ke berbagai negara di Dunia. Oleh sebab itu, pada hari Rabu tanggal 11 Maret 2020 WHO kemudian 
Adam Muhshi: Pembatasan Kebebasan Beragama...

menetapkan penyebaran virus korona sebagai sebuah pandemi global. ${ }^{1}$ Sebagai sebuah pandemi global, virus korona tersebut telah masuk dan menyebar pula ke Indonesia ${ }^{2}$ sehingga kemudian pada tanggal 31 Maret 2020 Presiden Jokowi menetapkan darurat kesehatan masyarakat melalui Keputusan Presiden Nomor 11 Tahun 2020 tentang Penetapan Kedaruratan Kesehatan Masyarakat Corona Virus Disease 2019 (Covid-19) [selanjutnya disebut Kepres Penetapan Darurat Kesehatan].

Penetapan kedaruratan kesehatan masyarakat oleh Presiden Jokowi melalui Kepres Darurat Kesehatan tersebut secara yuridis formal sudah tepat. Dikatakan demikian karena penetapan tersebut telah didasarkan dan sesuai dengan ketentuan Undang-Undang Nomor 6 Tahun 2018 tentang Kekarantinaan Kesehatan (selanjutnya disebut UU Kekarantinaan Kesehatan). ${ }^{3}$ Artinya, penetapan kadaruratan kesehatan masyarakat tersebut sudah sesuai dengan UU Kekarantinaan Kesehatan di mana UU ini oleh Majda El Muhtaj ${ }^{4}$ dikatakan sebagai wujud komitmen tegas Indonesia terhadap implementasi internasional health regulation (IHR).

Sayangnya, penetapan kedaruratan kesehatan masyarakat itu selanjutnya hanya diikuti kebijakan pembatasan sosial berskala besar sebagaimana diatur melalui Peraturan Pemerintah Nomor 21 Tahun 2020 tentang Pembatasan Sosial Berskala Besar dalam Rangka Percepatan Penanganan Corona Virus Disease 2019 (Covid-19) [selanjutnya disebut PPNomor 21 Tahun 2020]. Padahal dalam perspektif HAM ada pilihan kebijakan yang dinilai dapat lebih menjamin pemenuhan kebutuhan dasar warga negara, ${ }^{5}$ yaitu dengan penetapan bencana sebagaimana

\footnotetext{
${ }^{1}$ Kompas Cyber Media, 'WHO Umumkan Virus Corona sebagai Pandemi Global Halaman all' (KOMPAS.com) <https://www.kompas.com/global/read/2020/03/12/001124570/who-umumkan-virus-corona-sebagai-pandemi-global> accessed 16 June 2020.

2 Tim detikcom, 'Kapan Sebenarnya Corona Pertama Kali Masuk RI?' (detiknews) <https:/ / news.detik.com/berita/d-4991485/kapan-sebenarnya-corona-pertama-kali-masuk-ri> accessed 17 June 2020

${ }^{3}$ Vide Pasal 10 jo. Pasal 1 angka 2 UU Kekarantinaan Kesehatan.

${ }^{4}$ Majda El Muhtaj, ‘OPINI: Covid-19 dan Kedaruratan Kesehatan Nasional dalam Perspektif HAM' (kumparan) <https://kumparan.com/sumutnews/opini-covid-19-dan-kedaruratan-kesehatan-nasional-dalam-perspektif-ham-1t8ktLq6yUt> accessed 12 September 2021.

${ }^{5}$ Herlambang P Wiratraman, 'Perlindungan HAM Dalam Kehidupan' <https:/ / www.jawapos.com/opini/01/04/2020/perlindungan-ham-dalam-kehidupan/> accessed 12 September 2021.
} 
diperintahkan Undang-Undang Nomor 24 Tahun 2007 tentang Penanggulangan Bencana (selanjutnya disebut UU Penanggulangan Bencana) ${ }^{6}$ dan penetapan kedaruratan kesehatan masyarakat melalui karantina wilayah sebagaimana diamanahkan oleh UU Kekarantinaan Kesehatan. ${ }^{7}$ Dengan penetapan bencana dan penetapan kedaruratan kesehatan masyarakat tersebut, Pemerintah terikat pada kewajiban untuk menjamin ketersediaan sumber daya dalam rangka memenuhi kebutuhan hidup dasar yang dibutuhkan warga negara. ${ }^{8}$

Dalam perspektif ketatanegaraan, penetapan kedaruratan kesehatan masyarakat dengan pembatasan sosial berskala besar bermakna bahwa negara berada dalam status kedaruratan publik. Dalam kondisi demikian, Pasal 59 ayat (3) UU Kekarantinaan Kesehatan memberikan kewenangan kepada negara untuk melakukan pembatasan kegiatan warga negara guna menjamin dan melindungi kesehatan publik. Ketentuan Pasal 59 ayat (3) UU Kekarantinaan Kesehatan tersebut senafas dengan Pasal 4 ayat (1) Kovenan Internasional tentang HakHak Sipil dan Politik ${ }^{9}$ (selanjutnya disebut Kovenan Hak Sipil dan Politik) yang memberikan ruang kepada negara untuk melakukan pembatasan terhadap HAM sepanjang ia memang sangat diperlukan dalam kondisi darurat tersebut dan tidak diskriminatif.

Berdasarkan perintah Pasal 59 ayat (3) UU Kekarantinaan Kesehatan,, kebijakan pembatasan sosial berskala besar (social distancing) tersebut telah dilaksanakan oleh Pemerintah Indonesia dengan cara meliburkan sekolah, penyelenggaraan pendidikan jarak jauh (PJJ), bekerja dari rumah (work from home), pembatasan kegiatan keagamaan, serta pembatasan kegiatan yang melibatkan

${ }^{6}$ Vide Pasal 8 UU Penanggulangan Bencana.

${ }^{7}$ Vide Pasal 55 ayat (1) UU Kekarantinaan Kesehatan.

${ }^{8}$ Wiratraman HP, 'Perlindungan HAM Dalam Kehidupan' <https://www.jawapos.com/ opini/01/04/2020/perlindungan-ham-dalam-kehidupan/ > accessed 12 September 2021.

${ }^{9}$ Kovenan ini telah diratifikasi Indonesia melalui Undang-Undang Nomor 12 Tahun 2005 tentang Pengesahan International Convenant on Civil and Political Rights (Kovenan Internasional tentang Hak-Hak Sipil dan Politik). 2020).[4].

${ }_{10}$ Adam Muhshi, 'Darurat Kesehatan Dan Kepatuhan Masyarakat' Koran Sindo (14 April 
Adam Muhshi: Pembatasan Kebebasan Beragama...

banyak orang dan menimbulkan kerumunan. ${ }^{11}$ Akan tetapi beberapa pembatasan yang dilakukan dalam konteks darurat kesehatan berdasarkan UU Kekarantinaan Kesehatan tersebut mengalami banyak persoalan dalam pelaksanaannya. Beberapa persoalan yang mengemuka antara lain disparitas akses internet dalam konteks penyelenggaraan PJJ, banyaknya pemutusan hubungan kerja sebagai salah satu akibat peliburan tempat kerja, dan ketidakpatuhan masyarakat pada pembatasan kegiatan keagamaan. Dalam konteks tulisan ini, persoalan yang disebut terakhir yaitu ketidakpatuhan terhadap pembatasan kegiatan keagamaan akan dikaji lebih lanjut dalam frame pembatasan hak atas kebebasan beragama.

Selain diatur secara khusus dalam UU Kekarantinaan Kesehatan ketika terjadi darurat kesehatan, pembatasan terhadap kegiatan keagamaan juga memungkinkan untuk dilakukan secara konstitusional berdasarkan ketentuan Pasal 28J ayat (2) Undang-Undang Dasar Negara Republik Indonesia Tahun 1945 (selanjutnya disebut Konstitusi Indonesia). Pertanyaannya adalah sudah tepatkah pembatasan terhadap kegiatan keagamaan yang diterapkan oleh Pemerintah pada masa pandemi virus korona?, pertanyaan ini relevan diajukan untuk dicari jawabannya mengingat terjadinya pro dan kontra terhadapnya. ${ }^{12}$ Lebih dari itu, pro dan kontra telah pula menimbulkan perbedaan kepatuhan terhadap pembatasan kegiatan keagamaan tersebut dalam masyarakat di berbagai daerah yang pada gilirannya terdapat beberapa kasus penyelenggaraan kegiatan keagamaan menjadi kluster penyebaran virus korona. ${ }^{13}$

Ketikdapatuhan masyarakat tetap terjadi ketika Pemerintah menetapkan kebijakan Pemberlakuan Pembatasan Kegiatan Masyarakat (PPKM) Darurat yang diterapkan untuk wilayah Jawa dan Bali sejak tanggal 3 Juli sampai dengan 20

11 ibid.

${ }^{12}$ Okezone, 'Pro Kontra Larangan Sholat Jum'at di Tengah Wabah Corona: Okezone Tren' (https://www.okezone.com/, 19 March 2020) <https://www.okezone.com/tren/ $\mathrm{read} / 2020 / 03 / 19 / 620 / 2185963 /$ pro-kontra-larangan-sholat-jum-at-di-tengah-wabah-corona> accessed 18 June 2020; baca juga Syaifullah Amin, 'Peran Masjid di Tengah Wabah Corona' (detiknews) <https://news.detik.com/kolom/d-4955153/peran-masjid-di-tengah-wabah-corona> accessed 18 June 2020.

${ }^{13}$ Berkenaan dengan fakta ini misalnya baca '3 Fakta Terbaru Kasus COVID-19 Di Situbondo, Sebagian Besar Dari Klaster Masjid' (merdeka.com) <https://www.merdeka.com/jatim/3-fakta-terbaru-kasus-covid-19-di-situbondo-sebagian-besar-dari-klaster-masjid.html> accessed 24 June 2020. 
Juli 2021. ${ }^{14}$ PPKM Darurat tersebut diterapkan menyusul adanya penyebaran virus corona varian delta yang telah menelan banyak korban jiwa dimana salah satu pembatasan yang dilakukan berupa penutupan tempat ibadah. Akan tetapi, dalam realitasnya masih terjadi beberapa pelanggaran yang dapat dilihat dari adanya masjid di beberapa daerah yang tetap buka dan menyelenggarakan sholat berjamaah. ${ }^{15}$ Ketidakpatuhan tersebut tentu saja sangat dipengaruhi pemahaman masyarakat yang terbatas terhadap teks suci Al-Qur'an dan Al-Hadist. ${ }^{16}$ Padahal, virus korona merupakan pandemi global yang menyebabkan beberapa negara seperti Malaysia, Turki, Arab Saudi, Mesir dan yang lainnya mengambil kebijakan untuk menutup sementara masjid selama masa pandemi virus korona. ${ }^{17}$

Realitas terjadinya ketidakseragaman sikap dan kepatuhan masyarakat tersebut di atas merupakan bagian dari persoalan sosial kemasyarakatan yang menurut penulis berakar pada bagaimana memaknai kebebasan beragama dan syarat pembatasannya khususnya dalam keadaan darurat kesehatan. Oleh karena itu, terdapat urgensi untuk mengkaji hakikat kebebasan beragama dan pembatasannya dalam keadaan darurat kesehatan. Kajian akan dilakukan dalam konteks negara hukum Indonesia yang akan disandingkan dengan perspektif HAM internasional dan Islam. Perspektif HAM internasional penting diajukan mengingat

${ }^{14}$ Diktum Ketiga huruf g Instruksi Menteri Dalam Negeri Nomor 15 Tahun 2021 tentang Permberlakuan pembatasan Kegiatan Masyarakat Darurat Corona Virus Disease 2019 di Wilayah Jawa dan Bali menentukan bahwa tempat ibadah (masjid, mushola, gereja, pura, vihara, dan klenteng serta tempat umum lainnya yang difungsikan sebagai tempat ibadah) pada Kabupaten dan Kota di wilayah Jawa dan Bali yang termasuk kriteria level 3 dan level 4 ditutup sementara. Dalam perkembangannya ketentuan penutupan tempat ibadah ini diubah melalui Instruksi Menteri Dalam Negeri Nomor 19 Tahun 2021 tentang Perubahan Ketiga Instruksi Menteri Dalam Negeri Nomor 15 Tahun 2021 yang mulai diberlakukan sejak tanggal 10 Juli 2021. Diktum Kesatu Angka I menentukan bahwa "Tempat ibadah (Masjid, Mushola, gereja, Pura, Vihara, dan Klenteng serta tempat lainnya yang difungsikan sebagai tempat ibadah), tidak mengadakan kegiatan peribadatan/ keagamaan berjamaah selama masa penerapan PPKM Darurat dan mengoptimalkan pelaksanaan ibadah di rumah".

${ }^{15}$ Berkenaan dengan fakta ini misalnya baca Pradito Rida Pertana, 'Ada 700-an Masjid di Bantul Gelar Jumatan Berjemaah Saat PPKM Darurat' (detiknews) <https://news.detik.com/ berita-jawa-tengah/d-5646051/ada-700-an-masjid-di-bantul-gelar-jumatan-berjemaah-saat-ppkmdarurat> accessed 2 August 2021.

16 Baca Masyhudunnury, 'Analisis Penerapan Protokol Kesehatan Masyarakat Bangkalan: dari Interpretasi Kulturalis-Religiusitas ke Implementasi "Teks Suci”' (2021) 3 Journal of Islamic Civilization.[69-71].

${ }^{17}$ Berkenaan dengan fakta ini misalnya baca 'Arab Saudi Tutup Masjidil Haram Dan Masjid Nabawi Selama Ramadan - Dunia Tempo.Co' <https://dunia.tempo.co/read/1333753/arab-sauditutup-masjidil-haram-dan-masjid-nabawi-selama-ramadan> accessed 30 September 2021. 
Adam Muhshi: Pembatasan Kebebasan Beragama...

sifatnya yang universal dan juga telah diterimanya ia secara yuridis dalam sistem ketatanegaraan Indonesia. Sedangkan perspektif Islam diketengahkan mengingat Indonesia sebagai sebuah negara kebangsaan yang religius dimana Islam sebagai sebuah agama yang dianut oleh mayoritas penduduk Indonesia.

\section{Hakikat Kebebasan Beragama dan Pembatasannya}

Al Khanif mendefinisikan kebebasan beragama sebagai hak untuk memilih atau memiliki suatu agama atau kepercayaan yang meliputi hak untuk meyakini atau tidak meyakini sama sekali suatu agama baik yang bersifat theistik maupun yang non-theistik serta hak untuk memanifestasikan keyakinannya baik secara sendiri-sendiri maupun secara bersama-sama yang dilakukan di tempat umum atau di tempat yang bersifat privat. ${ }^{18}$ Pengertian itu ia kemukakan berdasarkan unsur-unsur dari ketentuan instrumen hukum internasional yang mengatur dan menjamin hak atas kebebasan beragama. ${ }^{19}$ Ketentuan-ketentuan tentang jaminan kebebasan beragama tersebut setidaknya diatur dalam Deklarasi Universal Hak Asasi Manusia (DUHAM), ${ }^{20}$ Kovenan Hak Sipil dan Politik, ${ }^{21}$ Deklarasi tentang Penghapusan Semua Bentuk Intoleransi dan Diskriminasi Berdasarkan Agama atau Kepercayaan, dan Deklarasi Hak Orang-Orang Minoritas secara Etnik, Bahasa dan Agama. ${ }^{22}$

Dalam perspektif instrument hukum internasional, konsep kebebasan beragama dibedakan menjadi dua bagian, yaitu: (1) kebebasan berpikir, meyakini dan menganut agama atau kepercayaan; dan (2) kebebasan untuk melaksanakan atau memanifestasikan agama dan kepercayannya tersebut. ${ }^{23}$ Secara toeritik, Arcot Krisnaswarni dan Asma Jahangir sebagaimana telah

\footnotetext{
${ }^{18}$ Al Khanif, Hukum \& Kebebasan Beragama Di Indonesia (LaksBang Mediatama 2010).[108].

19 ibid.

${ }^{20}$ Baca ketentuan Pasal 18 DUHAM.

${ }^{21}$ Baca ketentuan Pasal 18 Kovenan Hak Sipil dan Politik.

${ }^{22}$ Baca ketentuan Pasal 2 ayat (1) dan ayat (2) Deklarasi Hak Orang-Orang Minoritas secara Etnik, Bahasa dan Agama.

${ }^{23}$ Baca ketentuan Pasal 18 Kovenan Hak Sipil dan Politik dan Komentar Umum Nomor 22 angka 3 .
} 
dikutip oleh Al Khanif menyebut kebebasan untuk menganut dan meyakini agama dan kepercayaan sebagai unsur intenal (forum internum) dan kebebasan untuk menjalankan atau memanifestasikan agama dan kepercayaan sebagai unsur eksternal (forum externum). ${ }^{24}$

Pembagian konsep kebebasan beragama ke dalam forum internum dan forum externum tersebut menimbulkan konsekuensi hukum yang berbeda dalam sistem hukum ketatanegaran. Forum internum yang berupa kebebasan berpikir, meyakini, dan menganut agama atau kepercayaan tidak dapat dibatasi oleh negara meskipun dalam kondisi darurat. Sedangkan forum externum yang berupa kebebasan untuk menjalankan atau mengimplemtasikan agama dan kepercayaan memberikan ruang bagi negara untuk membatasinya. Namun, syarat pembatasannya pun sangat ketat di mana ia hanya dapat dibatasi melalui hukum. ${ }^{25}$

Selain harus dibatasi melalui hukum, pembatasan terhadap kebebasan beragama tersebut hanya dapat dilakukan apabila ia memang diperlukan untuk melindungi keamanan publik, ketertiban publik, kesehatan publik, atau moral publik atau kebebasan dan hak asasi orang lain. ${ }^{26}$ Artinya, pembatasan terhadap kebebasan beragama hanya dapat dilakukan apabila memang diperlukan atau dibutuhkan untuk melindungi salah satu dari lima hal tersebut. A contrario, apabila pembatasan tidak dibutuhkan untuk melindungi salah satu dari lima hal tersebut, maka ia tidak dapat dilakukan. Berkenaan dengan hal ini, Heiner Bielefeldt bahkan mengatakan bahwa pembatasan terhadap kebebasan beragama tidak sah apabila tujuan yang ingin dicapai dapat ditempuh dengan cara lain. ${ }^{27}$

Konsep kebebasan beragama yang telah didasarkan pada instrumen hukum internasional tersebut di atas tidaklah jauh berbeda dengan kebebasan beragama yang telah dijamin pula dalam Islam. Berkenaan dengan hal ini, Surat al-Kahf

${ }^{24}$ Khanif (n 18) 109-110; Adam Muhshi, Teologi Konstitusi: Hukum Hak Asasi Manusia Atas Kebebasan Beragama Di Indonesia (LKiS 2015).[23].

${ }^{25}$ Pasal 18 ayat (3) Konvenan Hak Sipil dan Politik.

${ }^{26}$ Pasal 18 ayat (3) Konvenan Hak Sipil dan Politik.

${ }^{27}$ Heiner Bielefeldt, Politik Kesetaraan: Dimensi-Dimensi Kebebasan Beragama Atau Berkeyakinan (Mizan 2019).[278]. 
Adam Muhshi: Pembatasan Kebebasan Beragama...

(18) ayat 29 telah menegaskan "Dan katakanlah (Muhammad), "Kebenaran itu datangnya dari Tuhanmu; barangsiapa menghendaki (beriman) hendaklah dia beriman, dan barang siapa menghendaki (kafir) biarlah dia kafir" ${ }^{28}$

Oleh sebab itu, dalam perspektif Islam tidak diperkenankan adanya pemaksaan untuk memeluk agama Islam. Hal ini sesuai dengan Al-Qur'an Surat al-Baqarah (2) ayat 256 yang menyatakan bahwa: ${ }^{29}$

“Tidak ada paksaan dalam (menganut) agama (Islam), sesungguhnya telah jelas (perbedaan) antara jalan yang benar dengan jalan yang sesat. Barang siapa ingkar terhadap thagut dan beriman kepada Allah, maka sungguh ia telah jelas jalan yang benar daripada jalan yang sesat. Karena itu barangsiapa yang ingkar kepada thagut dan beriman kepada Allah, maka sungguh ia telah berpegang pada tali yang sangat kuat yang tidak akan putus. Allah Maha Mendengar, Maha Mengetahui".

Berdasarkan Surah Al-Baqarah (2) ayat 256 tersebut, setiap individu diberikan kebebasan untuk memeluk atau tidak memelukagama Islam. ${ }^{30}$ Artinya bahwa Islam telah mengajarkan prinsip yang menjunjung tinggi kebebasan beragama. Oleh sebab itu, seorang Muslim tidak memiliki hak untuk memaksa non muslim untuk memeluk agama Islam. ${ }^{31}$ Dikatakan demikian karena Tuhan telah memberikan suatu kebebasan bagi tiap manusia untuk memilih apakah mau beriman atau tidak beriman. Apabila Tuhan berkehendak, sudah pasti semua orang dijadikan beriman semua di mana hal ini telah ditegaskan olehNya melalui Surat Yunus (10) ayat 99:32 “Dan jikalau Tuhanmu menghendaki, tentulah beriman semua orang di muka bumi seluruhnya. Maka Apakah kamu (hendak) memaksa supaya mereka menjadi orang-orang yang beriman semuanya?".

${ }^{28}$ Tafsir Al-Qur'an Tematik: Hubungan Antar-Umat Beragama (Cetakan Pertama, Lajnah Pentashihan Mushaf Al-Qur'an, Badan Litbang dan Diklat, Departemen Agama RI 2008).[30].

${ }^{29}$ ibid.[27].

${ }^{30}$ Kebebasan ini diberikan karena keimanan adalah berdasarkan kesadaran dan kerelaan serta hujjah dan bukti-bukti sehingga segala bentuk paksaan tidak ada gunanya. Wahbah az-Zuhaili, Tafsir Al-Munir: Aqidah, Syariah, \& Manhaj (Gema Insani 2013).[48].

${ }^{31}$ Berkenaan dengan Surat al-Baqarah (2) ayat 256 ini, Wahbah az-Zuhaili menyatakan bahwa Islam melarang sikap memaksa seseorang untuk memeluk Islam. Dan sebaliknya, Islam juga tidak membolehkan seseorang melakukan pemaksaan kepada salah satu keluarganya untuk keluar dari Islam. Baca lebih lanjut ibid 50.

${ }^{32}$ Tafsir Al-Qur'an Tematik: Hubungan Antar-Umat Beragama (n 28).[28]. 
Larangan pemaksaan untuk memeluk agama Islam tersebut mengandung makna bahwa dalam Islam terdapat prinsip toleransi. ${ }^{33}$ Artinya bahwa Islam memberikan kebebasan bagi setiap orang untuk memeluk agama Islam atau tidak memeluk agama Islam dan sekaligus untuk menjalankan ibadah sesuai dengan pilihan keyakinannya masing-masing. Kebebasan yang berkelindan dengan prinsip toleransi ini menimbulkan sebuah konsekuensi pertanggungjawaban masing-masing individu atas amal perbuatannya di akhirat kelak. ${ }^{34}$ Berkenaan dengan ini, Surat Saba' (34) ayat 25 menegaskan "Katakanlah, Kamu tidak akan dimintai tanggung jawab atas apa yang kami kerjakan dan kami juga tidak akan dimintai tanggung jawab atas apa yang kamu kerjakan".

SuratSaba' (34) ayat 25 tersebut diatas dalam Tafsir Al-Qur'an Tematik dikaitkan dengan kebebasan beragama dalam rangka mewujudkan kerukunan hidup antar pemeluk agama. Dikatakan bahwa dalam masyarakat yang plural, kerukunan hidup antar pemeluk agama harus diperjuangkan dengan catatan tidak mengorbankan aqidah sebagaimana telah digariskan dalam Surah al-Kafirun ayat 6, yaitu: "Bagimu agamamu dan bagiku agamaku" ${ }^{35}$ Berdasarkan surat al-Kafirun ayat 6 tersebut, dapat dikatakan bahwa Islam mengajarkan prinsip toleransi dalam kebebasan beragama yang bermakna bahwa Islam memberikan kebebasan untuk memilih agama sekaligus kebebasan untuk menjalankan ibadah ritual sesuai dengan agama dan kepercayaannya masing-masing. Oleh sebab itu, tidak boleh terjadi pemaksaan untuk meyakini suatu agama karena tanggung jawab atas pilihan tersebut akan dipikul masing-masing individu sebagaimana telah ditegaskan dalam Surah Saba' (34) ayat 25 di atas.

Pertanggungjawaban oleh masing-masing individu sebagaimana ditegaskan dalam Surat Saba (34) ayat 25 diatas telah tercermin pula dalam konsep "Lanaa a'maalunaa, walakum a'maalukum" yang tercantum dalam Surat Al-Baqarah (2).

${ }^{33}$ Dikatakan dalam Tafsir Al-Qur'an Tematik bahwa kebebasan untuk memeluk agama sesuai dengan keyakinannya merupakan syarat bagi terwujudnya sikap toleran dalam kehidupan beragama. Baca lebih lanjut ibid 26.

${ }^{34}$ Dalam menjelaskan Surat al-Kahf (18) ayat 29, Hamka mengatakan bahwa apabila seseorang memilih tidak beriman (kafir) atas kebebasan yang diberikan Allah untuk memilih untuk beriman atau tidak beriman, maka ia sendiri yang akan menanggung akibat kekafirannya tersebut bukan orang lain. Baca lebih lanjut Hamka, Tafsir Al-Azhar (Pustaka Nasional Pte Ltd 2001) 4.[191].

${ }^{35}$ Tafsir Al-Qur'an Tematik: Hubungan Antar-Umat Beragama (n 28).[41-42]. 
Adam Muhshi: Pembatasan Kebebasan Beragama...

Dalam hal ini Surat Al-Baqarah (2) ayat 139 menyatakan bahwa "Katakanlah 'Apakah kamu memperdebatkan dengan kami tentang Allah, padahal Dia adalah Tuhan kami dan Tuhan kamu; bagi kami amalan kami, bagi kamu amalan kamu dan hanya kepada-Nya kami mengikhlaskan hati" (cetak tebal oleh Penulis). ${ }^{36}$ Konsep pertanggungjawaban keyakinan dan amal perbuatan masing-masing individu dalam Islam tersebut tertuang pula dalam surat Asy-Syura (42) ayat 15 berikut:

"Karena itu, serulah (mereka beriman) dan tetaplah (beriman dan bertaqwalah) sebagaimana diperintahkan kepadamu (Muhammad) dan janganlah mengikuti hawa nafsu mereka dan katakanlah: "Aku beriman kepada semua kitab yang diturunkan Allah dan aku diperintahkan supaya berlaku adil di antara kamu. Allah Rabb kami dan Rabb kamu. Bagi kami amal perbuatan kami dan bagi kamu amal perbuatan kamu. Tidak (perlu) ada pertengkaran antara kami dan kamu, Allah mengumpulkan antara kita dan kepada-Nyalah (kita) kembali" ${ }^{37}$

Kemudian surat Yunus (10) ayat 41 menegaskan “Dan jika mereka mendustakanmu (Muhammad), maka katankanlah: "Bagiku pekerjaanku dan bagimu pekerjaanmu. Kamu tidak bertanggung jawab terhadap apa yang aku kerjakan dan akupun tidak bertanggung jawab terhadap apa yang kamu kerjakan". ${ }^{38}$ Selain itu, konsep lanaa a'maalunaa walakum a'malukum juga tercantum

${ }^{36}$ Berkenaan dengan konsep "Lanaa a'maalunaa, walakum a'maalukum" dalam Surat alBaqarah (2) ayat 139, Wahbah az-Zuhaili dalam tafsirnya menyatakan bahwa Allah akan membalas setiap manusia sesuai dengan amalnya. Tidak ada kelebihan di antara manusia kecuali dengan ketaqwaan dan amal saleh. Baca Wahbah az-Zuhaili, Tafsir Al-Munir: Aqidah, Syariah, E Manhaj, Jilid 1 (Jakarta: Gema Insani, 2013) at 264-266.

${ }^{37}$ Dalam tafsirnya terhadap konsep 'lanaa a'maalunaa, walakum a'maalukum' yang terdapat dalam Surat Asy-Syura (42) ayat 15 ini, Wahbah az-Zuhaili menyatakan bahwa 'Sesungguhnya ganjaran pahala dan hukuman atas amal perbuatan kami khusus bagi kami, begitu juga pahala dan hukuman atas amal perbuatan kalian adalah khusus bagi kalian'. Kami terbebas dari kalian dan amal kalian sebagaimana firman Allah SWT dalam Surat Saba' (34) ayat 25 dan Surat Yunus (10) ayat (41). Baca lebih lanjut Wahbah az-Zuhaili, Tafsir Al-Munir: Aqidah, Syari'ah, E Manhaj (Gema Insani 2016).[63-66].

${ }^{38}$ Konsep pertanggungajawaban amal perbuatan masing-masing individu sebagaimana tertuang dalam Surat Yunus (10) ayat 41 ini dalam tafsir Al-Munir dikaitkan dengan Surat Yunus (10) ayat 52: 'Kamu tidak diberi balasan, melainkan (sesuai) dengan apa yang telah kamu kerjakan'. Selain itu, dikatakan bahwa di dalamnya ada penegasan prinsip tanggung jawab pribadi yaitu bahwa tanggung jawab setiap manusia cuma terbatas pada dirinya sendiri dan tidak ada tuntutan tanggung jawab atas dosa orang lain di mana hal ini sesuai dengan firman Allah dalam Surat al-An'am (6) ayat 164: 'Dan seseorang tidak akan memikul beban dosa orang lain', dalam Surat as-Syu' ara (26) ayat 216: "Kemudian jika mereka mendurhakaimu maka katakanlah (Muhammad), 'Seungguhnya aku tidak bertanggung jawab terhadap apa yang kamu kerjakan', dalam Surat Huud (11) ayat 35: "Katakanlah (Muhammad), 'Jika aku mengada-ada, akulah yang akan memikul dosanya, dan aku bebas dari dosa yang kamu perbuat', dan dalam Surat Saba' (34) ayat 25 sebagaimana telah disampaikan sebelumnya di atas. Wahbah az-Zuhaili, Tafsir Al-Munir: Aqidah, Syari'ah, E Manhaj (Gema Insani 2016).[184]. 
dalam surat Al-Qashshash (28) ayat 55:39 "Dan apabila mereka mendengar perkataan yang buruk, mereka berpaling darinya dan mereka berkata, "Bagi kami amal-amal kami dan bagimu amal-amalmu, semoga selamatlah kamu, kami tidak ingin bergaul dengan orang-orang bodoh".

Konsep pertanggungjawaban yang dibebankan kepada setiap individu sesuai dengan amal perbuatannya masing-masing tersebut tentunya sudah sesuai dengan kodrat penciptaan manusia yang dilengkapi akal untuk berpikir dan memilih agama atau kepercayaannya. ${ }^{40}$ Artinya bahwa konsep pertanggungjawaban tersebut merupakan konsekuensi logis dari diberikannya kebebasan kepada setiap manusia untuk berpikir dan memilih keyakinannya masing-masing. Oleh sebab itu, logis kemudian ketika prinsip kebebasan atau kemerdekaan bagi setiap orang menjadi pilar utama dalam sebuah tatanan masyarakat yang dibangun berdasarkan nilai-nilai Al-Qur'an. ${ }^{41}$

Akan tetapi, kebebasan beragama dalam perspektif Islam tentu saja tidak bebas tanpa batas. Berkenaan dengan hal ini, dapat dikemukakan misalnya pendapat Uthman yang menyatakan bahwa meskipun negara Islam bertugas untuk memajukan agama Islam, namun tidak boleh kemudian ia memaksa seseorang untuk memeluk Islam. Justru sebaliknya negara wajib mengawasi dan mencegah pihak-pihak yang ingin menghalangi manusia dari kebebasan untuk menganut agama dan kepercayaan. ${ }^{42}$ Pendapat ini mengisyaratkan bahwa dalam perspektif Islam, negara memiliki kewenangan untuk membatasi kebebasan beragama manakala pelaksanaannya dapat mengganggu kebebasan orang lain.

Dalam konteks pembatasan ini, perlu dikemukakan pula bahwa Islam melarang penghinaan dan/atau penodaan terhadap agama lain. Islam sebagaimana

${ }^{39}$ Wahbah az-Zuhaili, Tafsir Al-Munir: Aqidah, Syari'ah, E Manhaj (Gema Insani 2016).[398-399].

${ }^{40}$ Dalam menguraikan Surat al-Kahf (18) ayat 29, Hamka menyatakan bahwa Allah telah memberi akal kepada manusia agar dapat menimbang dan mengunci kebenaran. Berbekal akal tersebutlah manusia bebas untuk memilih beriman atau tidak beriman yang tentu saja dengan konsekeunsi pertanggungjawaban atas pilihannya masing-masing. Baca lebih lanjut Hamka, supra note 23 at 4191 .

${ }^{41}$ Tafsir Al-Qur'an Tematik: Hubungan Antar-Umat Beragama (n 28).[30].

${ }^{42}$ Mashood A Baderin, Hukum Internasional Hak Asasi Manusia \& Hukum Islam (Komisi Nasional Hak Asasi Manusia 2010).[123]. 
Adam Muhshi: Pembatasan Kebebasan Beragama...

telah ditegaskan dalam Surat al-An'am (6) ayat 108 melarang umat muslim memaki atau mengumpat sesembahan pemeluk agama lain selain Allah. ${ }^{43}$ Dapat dikatakan bahwa secara substansial, Surat al-An'am tersebut memberikan petunjuk bahwa Islam mengajarkan prinsip toleransi dalam kehidupan beragama. Berdasar prinsip toleransi itulah, warga masyarakat dituntut untuk saling menghormati agama dan keyakinannya masing-masing sehingga kehidupan beragama yang damai dan tenteram akan tercipta.

Akan tetapi, pembatasan kebebasan beragama dalam perspektif Islam harus selalu dapat ditunjuk dasarnya dalam syari' at sebagai bentuk pertanggungjawaban kepada Allah. Sebab, tanggung jawab negara dalam Islam bukan hanya kepada manusia tetapi juga kepada Allah untuk tidak melanggar kebebasan dan kemerdekaan setiap warga negara tanpa justifikasi. Pada titik ini, dapat dikatakan bahwa pembatasan terhadap kebebasan beragama dalam Islam harus selalu dalam kerangka maqashid al syari'ah, yaitu untuk meningkatkan kemaslahatan dan mencegah kerusakan. Apabila pembatasan terhadap kebebasan beragama dilakukan tanpa adanya alasan yang dibenarkan oleh syari'ah tentu saja ia akan menimbulkan keburukan dalam kehidupan bermasyarakat.

Berdasarkan uraian di atas, dapat kita pahami bahwa baik HAM internasional maupun Islam sama-sama menjamin adanya kebebasan beragama. Selain itu, keduanya juga sama-sama memberi kewenangan kepada negara atau otoritas politik untuk melakukan pembatasan terhadap pelaksanaan kebebasan beragama. Pembatasan tersebut tentu saja dengan syarat yang ketat, di mana HAM internasional menentukan pembatasan hanya dapat dilakukan melalui hukum. Sedangkan Islam menggariskan bahwa pembatasan harus dapat ditunjuk dasar justifikasinya dalam syari'at.

${ }^{43}$ Sebab turunnya (asbabun-nuzul) ayat ini menurut satu riwayat, adalah adanya sebagian kecil orang Islam yang suka mengejek berhala-berhala tuhan kaum musyrikin. Mendengar hal ini mereka pun secara emosional mengejek Allah, bahkan kemudian mereka mengultimatum Nabi Muhammad dan orang-orang mukmin, mereka berkata, "Wahai Muhammad hanya ada dua pilihan, kamu tetap mencerca tuhan-tuhan kami, atau kami akan mencerca Tuhan- mu?." Baca lebih lanjut Tafsir Al_Qur'an Tematik: Hukum, Keadilan, Dan Hak Asasi Manusia (Lajnah Pentashihan Mushaf AlQur'an, Badan Litbang dan Diklat, Kementerian Agama RI 2010).[427]. 
Lalu bagaimana dengan kebebasan beragama di Indonesia? sebagai sebuah negara hukum, Indonesia sejak semula telah mengakui dan menjamin perlindungan kebebasan beragama dalam konstitusinya. ${ }^{44}$ Jaminan terhadap kebebasan beragama tersebut telah dilakukan oleh Indonesia tiga tahun sebelum lahirnya DUHAM.$^{45}$ Dalam perkembangannya, pada tahun 1999 sampai dengan tahun 2002 Konstitusi Indonesia diamandemen di mana pasca amandemen tersebut materinya secara umum semakin memperluas dan memperkuat jaminan konstitusional terhadap HAM yang tentu saja termasuk di dalamnya penguatan jaminan terhadap kebebasan beragama.

Penguatan jaminan konstitusional kebebasan beragama itu tampak dengan semakin bertambahnya ketentuan yang memberi jaminan perlindungan terhadap kebebasan beragama di Indonesia. Dikatakan demikian karena selain tetap mempertahankan ketentuan Pasal 29 ayat (2), jaminan konstitusional terhadap kebebasan beragama telah diatur pula dalam Pasal 28E ayat (1) dan ayat (2) serta Pasal 28I ayat (1) Konstitusi Indonesia. Lebih dari itu, penguatan tampak juga dengan hadirnya ketentuan yang memberi kewenangan kepada negara untuk dapat melakukan pembatasan terhadap kebebasan beragama. Pembatasan ini dikatakan sebagai penguatan terhadap kebebasan beragama karena secara teoritik pembatasan negara terhadap kebebasan sebagaimana telah dikemukakan John Rawls harus ditujukan dalam rangka untuk memperkuat seluruh sistem kebebasan itu sendiri serta untuk memastikan perlindungan terhadap kebebasan yang sama atau kebebasan dasar yang berbeda. ${ }^{46}$

Tujuan pembatasan untuk penguatan sebagaimana dikemukakan oleh John Rawls tersebut tampak dalam Konstitusi Indonesia yang menentukan bahwa pembatasan hanya dapat dilakukan jika dimaksudkan semata-mata untuk menjamin pengakuan dan penghormatan terhadap hak dan kebebasan orang

\footnotetext{
${ }^{44}$ Baca Pasal 29 Konstitusi Indonesia.

${ }^{45}$ Konstitusi Indonesia lahir pada tanggal 18 Agustus 1945, sedangkan DUHAM baru muncul pada tahun 1948.

${ }^{46}$ Adam Muhshi, Teologi Konstitusi: Hukum Hak Asasi Manusia Atas Kebebasan Beragama di Indonesia (n 24).[45].
} 
lain. ${ }^{47}$ Pembatasan terhadap kebebasan oleh negara juga hanya dapat dilakukan apabila dimaksudkan untuk memenuhi keadilan berdasarkan pertimbangan moral, nilai-nilai agama, keamanan, dan ketertiban umum. ${ }^{48}$ Dan tentu saja, pembatasan terhadap kebebasan beragama tersebut hanya dapat dibenarkan jika dilakukan melalui undang-undang. ${ }^{49}$

Maksud atau tujuan pembatasan yang telah digariskan oleh Konstitusi Indonesia tersebut agak berbeda jika dibandingkan dengan tujuan pembatasan yang diatur dalam Kovenan Sipol. Perbedaan itu terlihat dari munculnya frase "nilai-nilai agama" yang dapat dijadikan sebagai dasar pembatasan terhadap kebebasan beragama dalam konteks negara hukum Indonesia. Perbedaan lainnya, kesehatan publik yang menjadi salah satu alasan yang dapat dijadikan sebagai dasar pembenar dapat dilakukannya pembatasan terhadap kebebasan beragama oleh negara sebagaimana diatur dalam Kovenan Sipol tidak diatur dalam Konstitusi Indonesia.

Munculnya nilai-nilai agama sebagai salah satu tujuan yang dapat memberikan ruang bagi negara untuk melakukan pembatasan terhadap kebebasan beragama tidak dapat dilepaskan dari prinsip ketuhanan menjadi dasar negara Indonesia. Dikatakan demikian karena sejak awal, bangsa Indonesia telah memberi sebuah pengakuan bahwa kemerdekaan yang diraihnya hanya atas rahmat dan ijin Tuhan Yang Maha Esa. Oleh sebab itu, tidak berlebihan manakala Moh. Mahfud MD mengatakan bahwa meskipun Indonesia bukan negara agama tetapi ia bukan juga sebagai negara sekuler. Dikatakan olehnya bahwa Indonesia merupakan negara Pancasila, sebuah negara kebangsaan yang dijiwai oleh agama (religious nation state)..$^{50}$

Selanjutnya untuk perbedaan yang kedua, absennya kesehatan publik sebagai salah satu tujuan dapat dilakukannya pembatasan beragama dalam

${ }^{47}$ Vide Pasal 28J ayat (2) Konstitusi Indonesia.

${ }^{48}$ Vide Pasal 28J ayat (2) Konstitusi Indonesia.

${ }^{49}$ Vide Pasal 28J ayat (2) Konstitusi Indonesia.

${ }^{50}$ Adam Muhshi, Teologi Konstitusi: Hukum Hak Asasi Manusia Atas Kebebasan Beragama di Indonesia (n 24).[82]. 
Konstitusi Indoneia tidak kemudian berarti bahwa kesehatan publik tidak dapat dijadikan sebagai alasan pembatasan oleh negara. Artinya bahwa meskipun tidak disebutkan secara spesifik, namun kesehatan publik dapat dimasukkan pada tujuan pembatasan untuk menjamin pengakuan dan penghormatan terhadap hak dan kebebasan orang lain. Dikatakan demikian karena kesehatan merupakan salah satu HAM yang wajib dijamin pemenuhannya oleh negara.

\section{Pembatasan dalam Darurat Kesehatan}

Kebijakan pemerintah agar masyarakat beribadah di rumah saja dan tidak melakukannnya secara bersama-sama seperti di masjid, gereja, atau di tempattempat ibadah lainnya merupakan bagian dari forum externum. ${ }^{51}$ Pembatasan terhadap kegiatan keagamaan tersebut secara konstitusional memang dapat dilakukan oleh Pemerintah. Dikatakan demikian karena forum externum atau manifestasi dari agama atau kepercayaan tidak termasuk derogable rights yang secara konstitusional sama sekali tidak boleh dibatasi dalam keadaan apapun.

Oleh sebab itu, terhadap pembatasan kegiatan keagamaan berlaku ketentuan Pasal 28J ayat (2) Konstitusi Indonesia yang menentukan bahwa setiap orang dalam menjalankan hak dan kebebasannya wajib tunduk kepada pembatasan yang ditetapkan dengan undang-undang. Ketentuan Pasal 28J ayat (2) Konstitusi Indonesia tersebut sejalan dengan ketentuan Pasal 18 ayat (3) Konvenan Hak Sipil dan Politik yang menyatakan bahwa pembatasan harus ditentukan oleh hukum (prescribed by law). Dengan demikian, pembatasan terhadap kegiatan keagamaan dalam konteks negara hukum Indonesia wajib dilakukan melalui undang-undang. Secara a contrario, pembatasan yang dilakukan melalui jenis peraturan perundangundangan selain undang-undang secara konstitusional tidak diperkenankan.

Berdasarkan ketentuan konstitusional tersebut, maka pertanyaan berikutnya yang harus dicari jawabannya adalah apakah pembatasan terhadap kegiatan

${ }^{51}$ Berdasarkan Deklarasi tentang Penghapusan Semua Intoleransi dan Diskriminasi berdasarkan Agama dan Kepercayaan, melaksanakan ibadah merupakan salah satu bagian dari Forum externum atau kebebasan untuk memanifestasikan kebebasan beragama. 
Adam Muhshi: Pembatasan Kebebasan Beragama...

keagamaan dalam keadaan darurat virus korona dilakukan melalui undangundang. Terhadap pertanyaan ini, dapat dikemukakan bahwa pembatasan terhadap kegiatan keagamaan dalam keadaan darurat kesehatan telah diatur oleh Pasal 59 ayat (3) UU Kekarantinaan Kesehatan. Dalam hal ini Pasal 59 ayat (3) UU Kekarantinaan Kesehatan menentukan bahwa PSBB setidaknya meliputi peliburan sekolah dan tempat kerja, pembatasan kegiatan keagamaan, dan/atau pembatasan kegiatan di tempat atau fasilitas umum.

Pembatasan kegiatan keagamaan sebagai bagian dari PSBB tersebut merupakan pembatasan yang dilakukan dalam rangka keadaan darurat kesehatan. Hal ini sesuai dengan ketentuan Pasal 59 ayat (1) UU Kekarantinaan Kesehatan yang menyatakan bahwa PSBB merupakan bagian dari respon terhadap kedaruratan kesehatan masyarakat. Dengan demikian, pembatasan kegiatan keagamaan yang merupakan bagian dari PSBB harus didahului pernyataan keadaan darurat oleh Presiden. Itu sebab, kemudian Presiden mengeluarkan Kepres Penetapan Darurat Kesehatan.

Terbitnya Kepres Penetapan Darurat Kesehatan tersebut telah sesuai dengan perintah Pasal 10 UU Kekarantinaan Kesehatan. Pasal 10 UU Kekarantinaan Kesehatan tersebut telah memberikan kewenangan kepada Presiden untuk menetapkan dan mencabut kedaruratan kesehatan masyarakat berdasarkan jenis penyakit yang sedang mengjangkiti masyarakat dan faktor resikonya. Berdasarkan ketentuan Pasal 10 UU Kekarantinaan Kesehatan tersebut, penetapan kedaruratan kesehatan masyarakat memang harus berbentuk keputusan tata usaha negara (beschikking) dari Presiden.

Oleh sebab itu, Herlambang P. Wiratraman memberikan apresiasi atas terbitnya Kepres Penetapan Darurat Kesehatan tersebut. Apresiasi ia berikan berdasarkan dua alasan, yaitu: ${ }^{52}$ pertama, ia mengatakan bahwa bentuk penetapan kedaruratan kesehatan masyarakat melalui Kepres (beschikking) sudah tepat sebagai prasyarat terbitnya peraturan pemerintah sesuai dengan perintah Pasal

\footnotetext{
${ }^{52}$ Wiratraman (n 5). Loc. Cit.
} 
10 ayat (1), ayat (2), dan ayat (3) UU Kekarantinaan Kesehatan. Kedua, Terbitnya Kepres Penetapan Darurat Kesehatan telah didasarkan pada keadaan bahaya yang secara normatif merujuk pada ketentuan Pasal 1 angka 2 UU Kekarantinaan Kesehatan yang menentukan bahwa: "Kadaruratan Kesehatan masyarakat adalah kejadian kesehatan masyarakat yang bersifat luar biasa dengan ditandai penyebaran penyakit menular dan/atau kejadian yang disebabkan oleh radiasi nuklir, pencemaran biologi, kontaminasi kimia, bioterorisme, dan pangan yang menimbulkan bahaya kesehatan dan berpotensi menyebar lintas wilayah atau lintas negara".

Berdasarkan konstruksi hukum di atas, dapat dikatakan bahwa pembatasan kegiatan keagamaan yang berupa larangan untuk melaksanakan kegiatan keagamaan secara bersama-sama di tempat ibadah dalam keadaan darurat kesehatan virus korona sudah tepat dan memang perlu dilakukan oleh Pemerintah. Dikatakan demikian karena penyebaran virus korona dimungkinkan terjadi ketika adanya kontak fisik sehingga kemudian diperlukan untuk menjaga jarak fisik selama pandemi korona. Oleh sebab itu, menjadi sangat beralasan bagi pemerintah untuk melakukan pembatasan terhadap kegiatan keagamaan yang dilakukan secara bersama-sama di tempat ibadah sebagai bagian dari PSBB.

Kegiatan keagamaan yang dilakukan secara bersama-sama di tempat ibadah berpotensi menimbulkan terjadinya kontak fisik yang notabene dapat menjadi penyebab dari semakin meluasnya penyebaran virus korona. Artinya bahwa apabila kegiatan keagamaan yang dilakukan secara bersama-sama di tempat ibadah tidak dilarang, maka hal itu akan menimbulkan ancaman dan/atau dapat membahayakan kesehatan masyarakat. Ancaman terhadap kesehatan masyarakat inilah yang menjadi salah satu hal yang dapat dijadikan sebagai dasar pembatasan terhadap manifestasi kebebasan beragama (forum externum).

Kesehatan masyarakat merupakan hal yang wajib dilindungi sehingga ia menjadi salah satu hal yang dapat dijadikan sebagai dasar diperbolehkannya dilakukan pembatasan terhadap manifestasi kebebasan beragama. Hal ini sesuai dengan ketentuan Pasal 18 ayat (3) Kovenan tentang Hak Sipil dan Politik yang 
menentukan bahwa kebebasan menjalankan agama atau kepercayaan hanya dapat dibatasi apabila dilakukan dan diperlukan untuk melindungi keselamatan masyarakat, ketertiban masyarakat, kesehatan masyarakat, atau moral masyarakat, atau hak-hak dan kebebasan mendasar orang lain.

Berkenaan dengan konsep kesehatan masyarakat, Zainal Abidin Bagir dkk mendefinisikannya sebagai semua usaha yang dilakukan dalam rangka mencegah terjangkit penyakit, mempromosikan kesehatan, serta mendorong harapan hidup yang lebih baik bagi masyarakat. ${ }^{53}$ Lebih jauh, Zainal Abidin Bagir dkk menyatakan bahwa kesehatan masyarakat tidak hanya tentang penyakitnya tetapi perilaku individu atau masyarakat yang mengancam dan membahayakan kesehatan, apalagi hal itu dapat menular dan meluas. ${ }^{54}$

Berdasarkan konsep kesehatan masyarakat tersebut, dapat dikatakan bahwa dalam konteks pembatasan terhadap kebebasan beragama include di dalamnya perlindungan terhadap kebebasan dan hak-hak fundamental orang lain. Artinya bahwa pembatasan kegiatan keagamaan yang dilakukan secara bersama-sama di tempat ibadah memang perlu dilakukan karena ia dapat menyebabkan semakin meluasnya penularan virus korona. Penularan virus korona ini tentu saja bersinggungan dan dapat menggangu hak atas kesehatan dan/atau hak hidup orang lain.

Pelaksanaan kegiatan keagamaan yang bersinggungan dan berpotensi merugikan hak atas kesehatan dan/atau hak hidup orang lain menemukan relevansinya dengan harm principle yang telah dikemukakan oleh John Stuart Mill. Prinsip ini bermakna bahwa setiap individu bebas melakukan apa saja dalam rangka mengekspresikan hak-haknya selama ia tidak bersinggungan dan menimbulkan kerugian atau mengganggu hak orang lain. Berdasarkan prinsip tersebut, jelas bahwa kebebasan seseorang dalam mengekpresikan hakhaknya terbatas dan dibatasi oleh kebebasan dan hak-hak fundamental orang

${ }^{53}$ Zainal Abidin Bagir and others, Membatasi Tanpa Melanggar; Hak Kebebasan Beragama Atau Berkeyakinan (Center for Religious and Cross-cultural Studies (CRCS) UGM 2019).[48].

${ }^{54}$ ibid. [49]. 
lain..$^{55}$ Artinya bahwa kebebasan tidak bebas tanpa batas sehingga secara hukum negara mempunyai kewenangan untuk membatasi kebebasan individu dalam mengekpresikan hak-hanya agar tidak menimbulkan kerugian pada kebebasan dan hak-hak fundamental orang lain. ${ }^{56}$

Legitimasi negara untuk membatasi kegiatan keagamaan yang dapat menyebabkan penyebaran penularan virus korona tersebut, secara teoritis dapat pula disandingkan dengan pendapat John Rawls tentang syarat pembatasan terhadap kebebasan. Ia menyatakan bahwa kebebasan hanya dapat dibatasi oleh kebebasan itu sendiri, yaitu hanya jika: pertama, pembatasan itu akan memperkuat seluruh sistem kebebasan yang dinikmati oleh semua orang; dankedua, pembatasan dilakukan dalam rangka untuk memastikan kebebasan yang sama atau kebebasan dasar yang berbeda dilindungi dengan baik. ${ }^{57}$

Syarat pembatasan yang ketat dari John Rawls tersebut merupakan konsekuensi logis dari teori keadilan yang dikemukakannya untuk menentang teori keadilan utilitarian..$^{58}$ Menurutnya, setiap orang mempunyai kekebalan atas hak-haknya sehingga kesejahteraan masyarakat sekalipun tidak dapat digunakan sebagai dasar untuk menghapus kebebasan tersebut. ${ }^{59} \mathrm{Hal}$ ini dapat dipahami dari pernyataan John Rawls berikut: ${ }^{60}$

"Keadilan menolak jika hilangnya kebebasan sebagian orang dapat dibenarkan atas dasar manfaat lebih besar yang didapatkan oleh orangorang lain. Keadilan tidak membiarkan pengorbanan yang dipaksakan pada segelintir orang diperberat oleh sebagian besar keuntungan yang dinikmati banyak orang. Oleh sebab itu, dalam masyarakat yang adil kebebasan warga negara tetap tidak berubah, hak-hak yang dijamin oleh keadilan tidak tunduk pada tawar-menawar politik ataupun pada pertimbangan kepentingan sosial".

\footnotetext{
${ }^{55}$ Marett Leiboff and Mark Thomas dalam Adam Muhshi, Teologi Konstitusi; Hukum Hak Asasi Manusia Atas Kebebasan Beragama Di Indonesia (LKiS 2015).[40-41].

56 ibid. [ 40].

${ }^{57}$ John Rawls sebagaimana dikutip oleh ibid 45.

58 ibid. [46].

59 ibid.

${ }^{60}$ Jhon Rawls, Teori Keadilan; Dasar-Dasar Filsafat Politik Untuk Mewujudkan Sosial Dalam Negara (Pustaka Pelajar 2006).[126].
} 
Adam Muhshi: Pembatasan Kebebasan Beragama...

Pembatasan terhadap kebebasan beragama yang kemudian dikaitkan dengan keadilan pada akhirnya membawa kita pada suatu formula bahwa pembatasan terhadap kebebasan beragam tersebut tidak boleh diskriminatif. Berkenaan dengan ini, Pasal 28I ayat (2) Konstitusi Indonesia menentukan bahwa "Setiap orang berhak bebas dari perlakuan yang bersifat diskriminatif ...". Secara lebih khusus berkenaan dengan pembatasan kebebasan beragama, Komentar Umum Nomor 22 angka 8 Kovenan Hak Sipil dan Politik menyatakan bahwa "'Pembatasan tidak boleh diterapkan untuk tujuan-tujuan yang diskriminatif atau diterapkan dengan cara yang diskriminatif" ${ }^{61}$

Dalam konteks pembatasan terhadap kegiatan keagamaan dalam darurat kesehatan virus korona di Indonesia, pembatasan telah dilakukan berdasarkan atas hak kesetaraan (adil) dan non diskriminasi. Dikatakan demikian karena sejak awal penerapan social distancing berdasarkan himbauan Preisden Jokowi, pembatasan dilakukan terhadap semua agama atau kepercayaan. Presiden Jokowi pada kesempatan itu, menyampaikan secara umum agar masyarakat melaksanakan ibadah di rumah saja. ${ }^{62}$ Artinya bahwa, pembatasan kegiatan keagamaan yang dilakukan secara bersamasama di tempat ibadah berlaku untuk semua agama dan aliran kepercayaan.

Akan tetapi dalam realitasnya, ternyata masih banyak pelanggaranpelanggaran terhadap pembatasan tersebut. Pelaksanaan kegiatan keagamaan secara bersama-sama di tempat ibadah dalam prakteknya masih banyak dilakukan oleh masyarakat. Terhadap ketidakpatuhan tersebut, seyogianya pemerintah mengambil tindakan tegas karena pembiaran terhadap terjadinya pelanggaran sama artinya dengan membiarkan terjadinya diskriminasi terhadap pembatasan kebebasan kegiatan keagamaan tersebut.

Pembatasan kegiatan keagamaan yang dilakukan oleh Pemerintah tersebut dalam perspektif Islam sudah tepat. Dikatakan demikian karena adanya faktor

${ }^{61}$ Komentar Umum Kovenan Internasional Hak Sipil Dan Politik Hak Ekonomi Dan Sosial Budaya (Komisi Nasional Hak Asasi Manusia 2009).[52].

${ }^{62}$ Liputan6.com, 'Imbauan Jokowi terkait Covid-19, dari Kerja dari Rumah hingga Ingatkan Social Distancing' (liputan6.com, 16 March 2020) < https:/ / www.liputan6.com/news/read/4202629/ imbauan-jokowi-terkait-covid-19-dari-kerja-dari-rumah-hingga-ingatkan-social-distancing>accessed 17 June 2020. 
pencegah berupa penularan virus korona yang sangat membahayakan diri sendiri dan orang lain. Ketika ada faktor pencegah, ${ }^{63}$ maka berlaku hukum wadh'iyah yaitu bahwa timbulnya faktor pencegah menyebabkan gugurnya sebuah kewajiban. Artinya bahwa ibadah yang wajib dilakukan secara berjamaah seperti sholat Jum'at dapat ditinggalkan dan diganti dengan sholat dhuhur selama penularan virus corona sedang mengganas. Jika yang wajib saja menjadi gugur karena adanya faktor pencegah tersebut, maka apalagi kegiatan-kegiatan kegamaan bersama yang hukumnya hanya sunah.

Lebih dari itu, Nabi Muhammad telah bersabda bahwa tidak beriman seseorang sehingga ia mencintai orang lain sebagaimana ia mencintai dirinya sendiri (Riwayat al-Bukhari). ${ }^{64}$ Berdasarkan hadist ini, melakukan kegiatan keagamaan secara bersama-sama di tempat ibadah dalam kondisi penularan virus korona yang dapat membahayakan kesehatan dan/atau jiwa satu sama lain jelas bertentangan dengan perintah Nabi Muhammad kepada umatnya untuk mencintai orang lain seperti mencintai diri sendiri. Pemaknaan seperti ini sejalan dengan Hadist yang lain, yaitu:65 "Dari Aisyah, Rasulullah bersabda: “Tidak boleh ada bahaya dan tidak boleh membahayakan orang lain". Dengan demikian, dapat dikatakan bahwa dalam perspektif Islam negara memiliki kewenangan untuk membatasi individu dalam bertindak agar tidak menimbulkan kerugian pada orang lain.

Berkenaan dengan penyebaran virus korona yang dapat membahayakan kesehatan dan/atau jiwa tersebut, perlu dikemukakan pendapat Abdul Wahhab Khallaf yang menyatakan bahwa ketika ada uzur kesulitan, maka mukallaf dapat memilih untuk mengikuti rukhshah demi keringan untuknya atau untuk mengikuti 'azimah apabila sanggup menghadapi kesulitannya. Namun apabila kesulitan itu

\footnotetext{
${ }^{63}$ Faktor pencegah ini dalam hukum wadh'iyah dikenal dengan istilah mani' (penghalang) yang oleh ulama ushul fiqh didefinisikan sebagai sesuatu yang ditemukan setelah terbukti sebabnya dan memenuhi syaratnya tetapi dapat menghalangi hubungan sebab dan akibat. Baca lebih lanjut Abdul Wahhab Khallaf, Ilmu Ushul Fikih: Kaedah Hukum Islam (Jakarta: Pustaka Amani, 2003) at 166.

${ }^{64}$ Tafsir Al-Qur'an Tematik: Hubungan Antar-Umat Beragama (n 28).[80].

${ }^{65}$ Mukran H. Usman, Aswar Aswar and Andi Wahyu Irawan, 'Syariat Islam dan Kemaslahatan Manusia di Era New Normal pada Kegiataan Keagamaan dan Pendidikan' (2020) 12 FENOMENA.[89-96].
} 
Adam Muhshi: Pembatasan Kebebasan Beragama...

dapat mendatangkan bahaya, maka mukallaf wajib mengikuti rukhshah untuk menghindari bahaya tersebut. ${ }^{66}$ Pendapatnya tersebut didasarkan pada firman Allah dalam Surat al-Baqarah (2) ayat 195: "Dan janganlah kamu menjatuhkan tanganmu sendiri ke dalam kebinasaan" dan Surat an-Nisaa' (4) ayat 29: "Dan janganlah kamu membunuh dirimu" ${ }^{67}$

Penularan virus korona yang sangat membahayakan kesehatan dan/atau jiwa diri sendiri maupun orang lain tersebut tentu saja dapat dikategorikan sebagai sebuah bentuk kerusakan. Oleh sebab itu, maka berlakulah kaidah ushul fiqh "Dar'ul mafaasid muqoddamu 'ala jalbil mushoolihi" yang bermakna mencegah kerusakan (mafsadat) lebih didahulukan daripada meraih/mengerjakan kebaikan (maslahat). ${ }^{68}$ Berdasarkan kaidah ushul fiqh ini, maka dapat dikatakan bahwa menghindari kerusakan berupa penularan virus korona yang sangat membahayakan kesehatan dan/atau jiwa diri sendiri maupun orang lain harus didahulukan daripada mengerjakan kebaikan berupa kegiatan-kegiatan keagamaan yang dilakukan secara bersama-sama di tempat ibadah dalam kondisi pandemi korona yang sedang mengganas seperti saat ini.

Secara lebih luas, pencegahan kerusakan tersebut sesuai dengan maqashid al-syari'ah atau tujuan syari'at yang telah dikemukakan oleh alSyatibi sebagaimana dikutip oleh Mashood A Baderin, yaitu "Peningkatan kemaslahatan manusia (maslahah) dan pencegahan kerusakan (mafsadah)". ${ }^{69}$ Berkaitan dengan hal ini, Mashood A Baderin lebih lanjut menyampaikan pengertian istilah maslahah secara harfiah sebagai kepentingan atau kesejahteraan di mana dalam arti yang lebih sempit ia telah digunakan dalam fiqh Maliki untuk mengungkapkan prinsip kepentigan publik atau kesejahteraan publik yang kerap diberi syarat dengan mashlahah mursalah

${ }^{66}$ Khallaf (n 63).[174].

${ }^{67}$ ibid.

${ }^{68}$ Zamakhsyari bin Hasballah Thaib, ‘Pandangan Agama Islam Dalam Menghadapi Wabah Covid 19 Dan New Normal' (Webinar "Pandangan Agama Islam dalam Menghadapi Wabah Covid-19 dan New Normal, kerja sama Universitas Sumatera Utara dengan Pemerintah Kota Medan, Medan, 23 July 2020).[7].

${ }^{69}$ Baderin (n 42).[39]. 
ketika kepentingan tersebut tidak terikat pada otoritas tekstual khusus namun didasarkan pada pertimbangan kebaikan bersama. ${ }^{70}$

Argumentasi di atas bukan berarti menegasikan kemutlakan kebaikan sholat berjamaah yang dilakukan di masjid apalagi tentang sholat wajib jum'at. Sebab, tidak ada satupun syari'at yang buruk karena syari'at itu pasti koheren dengan maslahat (kebaikan). Tapi kemutlakan tersebut ketika pada masa normal. Dalam keadaan darurat kesehatan virus korona yang sedang mengganas, hal tersebut malah berpotensi untuk mendatangkan mafsadat (kerusakan) terhadap kesehatan dan/atau jiwa diri sendiri ataupun orang lain. ${ }^{71} \mathrm{Nah}$, mafsadat ini harus dihindari karena tentu saja bertentangan dengan tujuan ditetapkannya syari'ah, yaitu meningkatkan maslahat ${ }^{72}$ dan menghindari mafsadat.

Berdasarkan argumentasi di atas, maka sangat logis manakala pemerintah melakukan pembatasan terhadap kegiatan-kegiatan keagamaan yang dilakukan secara bersama-sama di tempat ibadah. Pembatasan yang diterapkan oleh Pemerintah tersebut tentu saja wajib diaati mengingat ia sebagai sebuah ketentuan atau perintah dari ulil amri. Kewajiban untuk taat perintah ulil amri ini sesuai dengan firman Allah Swt. dalam Surat an-Nisa' (4) ayat 59, yaitu: “Wahai orangorang yang beriman, taatilah Allah dan taatilah Rasul (Muhammad), dan Ulil Amri (pemegang kekuasaan) di antara kamu".

\section{Kesimpulan}

Kebebasan beragama sebagaimana HAM yang lainnya dijamin perlindungannya dalam instrumen hukum internasional. Demikian pula

\section{${ }^{70}$ ibid.[42].}

${ }^{71}$ Menjaga jiwa dalam perspektif Islam merupakan salah satu dari al-kulliyah al-khamsah yang menurut al-Ghazali dan al-Syatibi dianggap sebagai usul al-syariah dan merupakan tujuan umum dari pembuatan syariah. Baca lebih lanjut Galuh Nashrullah Kartika Mayangsari R and Hasni Noor, 'Konsep Maqashid Al-Syariah Dalam Menentukan Hukum Islam' (2014) 1 57; dan Agus Hermanto, 'Konsep Maslahat dalam Menyikapi Masalah Kontemporer (Studi Komparatif al-Tûfi dan al-Ghazali)' (2017) 14 AL-'ADALAH 433.[446].

${ }^{72}$ Menurut Muhammad Thohir Hakim, konsep mengambil maslahat dalam hubungannya dengan menjaga al-kulliyah al-khamsah, yaitu menjaga agama, jiwa, akal, keturuan, dan harta benda merupakan suatu kewajiban di mana para ulama Islam telah menetapkannya sebagai maslahat yang sifatnya darurat. Baca lebih lanjut H. Usman, Aswar and Irawan (n 65).[94]. 
Adam Muhshi: Pembatasan Kebebasan Beragama...

dalam Islam, HAM termasuk kebebasan beragama tersebut telah dijamin perlindungannya jauh sebelum DUHAM dilakukan. Dalam perspektif HAM internasional, implementasi atas kebebasan beragama yang bersinggungan dan dapat mengganggu kebebasan yang sama atau hak fundamental orang lain dapat dibatasi oleh negara yang tentu saja pembatasannya harus dilakukan melalui hukum. Sedangkan dalam perspektif Islam, pembatasan terhadap pelaksanaan hak atas kebebasan beragama secara umum dapat dikaitkan dengan doktrin maqashid al-syari'ah yang pada prinsipnya adalah rahmatan lil 'alamin. Islam diturunkan untuk kemaslahatan manusia, bukan sebaliknya untuk kerusakan (mafsadat) bagi manusia. Hal ini bermakna bahwa pelaksanaan hak atas kebebasan beragama tersebut dapat dibatasi apabila terdapat justifikasinya secara syari'ah dalam bingkai rahmatan lil ‘alamin.

Dalam perspektif HAM maupun dalam perspektif hukum Islam, pembatasan kegiatan kegamaan yang dilakukan secara bersama-sama di tempat ibadah dalam kondisi darurat kesehatan dapat dilakukan oleh negara. Dalam Islam, perintah untuk melaksanakan ibadah atau ritual bukan hanya sekedar bentuk penghambaan kepada Allah tetapi ia bertujuan untuk kebaikan diri sendiri dan orang lain. Tujuan beragama tidak lain adalah untuk kesejahteraan dan keamanan diri dan orang lain baik dunia maupun akhirat dalam bingkai konsep rahmatan lil 'alamin. Dalam konteks negara hukum Indonesia, pembatasan kegiatan keagamaan yang dilakukan secara bersama-sama di tempat ibadah selama masa pandemi korona secara konstitusional dapat dilakukan oleh Pemerintah. Pembatasan tersebut dilakukan berdasarkan ketentuan Pasal 59 ayat (3) UU Kekarantinaan Kesehatan di mana terhadapnya telah didahului oleh penetapan keadaan darurat kesehatan oleh Presiden Jokowi. Pembatasan niscaya dilakukan oleh Pemerintah untuk melindungi kesehatan masyarakat dan sekaligus include di dalamnya untuk melindungi kebebasan dan hak fundamental orang lain. Pembatasan tersebut telah pula diterapkan secara setara (adil) dan non diskriminasi. 


\section{Daftar Bacaan}

Buku

Abdul Wahhab Khallaf, Ilmu Ushul Fikih: Kaedah Hukum Islam (Pustaka Amani 2003).

Adam Muhshi, Teologi Konstitusi:Hukum Hak Asasi Manusia Atas Kebebasan Beragama Di Indonesia (LKiS 2015).

Al Khanif Hukum \& Kebebasan Beragama Di Indonesia (LaksBang Mediatama 2010).

Hamka, Tafsir Al-Azhar (Pustaka Nasional Pte Ltd 2001).

Heiner Bielefeldt, Politik Kesetaraan: Dimensi-Dimensi Kebebasan Beragama Atau Berkeyakinan (Mizan 2019).

John Rawls, Teori Keadilan; Dasar-Dasar Filsafat Politik Untuk Mewujudkan Sosial Dalam Negara (Pustaka Pelajar 2006).

Komentar Umum Kovenan Internasional Hak Sipil Dan Politik Hak Ekonomi Dan Sosial Budaya (Komisi Nasional Hak Asasi Manusia 2009).

Mashood A. Baderin, Hukum Internasional Hak Asasi Manusia \& Hukum Islam (Komisi Nasional Hak Asasi Manusia 2010).

Tafsir Al_Qur'an Tematik: Hukum, Keadilan, Dan Hak Asasi Manusia (Lajnah Pentashihan Mushaf Al-Qur'an, Badan Litbang dan Diklat, Kementerian Agama RI 2010).

Tafsir Al-Qur'an Tematik: Hubungan Antar-Umat Beragama (Cetakan Pertama, Lajnah Pentashihan Mushaf Al-Qur'an, Badan Litbang dan Diklat, Departemen Agama RI 2008).

Wahbah Az-Zuhaili, Tafsir Al-Munir: Aqidah, Syariah, E Manhaj (Gema Insani 2013).

_ - , Tafsir Al-Munir: Aqidah, Syari'ah, E Manhaj (Gema Insani 2016).

_- , Tafsir Al-Munir: Aqidah, Syari'ah, E Manhaj (Gema Insani 2016).

_ - , Tafsir Al-Munir: Aqidah, Syari'ah, E Manhaj (Gema Insani 2016).

_- , Tafsir Al-Munir: Aqidah, Syariah, \& Manhaj (Gema Insani 2013).

Zainal Abidin Bagir and others, Membatasi Tanpa Melanggar; Hak Kebebasan Beragama Atau Berkeyakinan (Center for Religious and Cross-cultural Studies (CRCS) 
Adam Muhshi: Pembatasan Kebebasan Beragama...

UGM 2019).

Jurnal

Agus Hermanto, 'Konsep Maslahat dalam Menyikapi Masalah Kontemporer (Studi Komparatif al-Tûfi dan al-Ghazali)' (2017) 14 AL-'ADALAH.

Galuh Nasrullah Kartika MR, Hasni Noor 'Konsep Maqashid Al-Syariah Dalam Menentukan Hukum Islam' (2014) 1 Al Iqtishadiyah.

Masyhudunnury, 'Analisis Penerapan Protokol Kesehatan Masyarakat Bangkalan: dari Interpretasi Kulturalis-Religiusitas ke Implementasi “Teks Suci"' (2021) 3 Journal of Islamic Civilization.

Mukran H. Usman, et.al, 'Syariat Islam dan Kemaslahatan Manusia di Era New Normal pada Kegiataan Keagamaan dan Pendidikan' (2020) 12 FENOMENA: Jurnal Penelitian.

\section{Karya Ilmiah}

Adam Muhshi, 'Darurat Kesehatan Dan Kepatuhan Masyarakat' Koran Sindo (14 April 2020) 4.

Thaib Z bin H, ‘Pandangan Agama Islam Dalam Menghadapi Wabah Covid 19 Dan New Normal' (Webinar "Pandangan Agama Islam dalam Menghadapi Wabah Covid-19 dan New Normal, kerja sama Universitas Sumatera Utara dengan Pemerintah Kota Medan, Medan, 23 July 2020).

\section{Laman}

3 Fakta Terbaru Kasus COVID-19 Di Situbondo, Sebagian Besar Dari Klaster Masjid' (merdeka.com) <https://www.merdeka.com/jatim/3-fakta-terbarukasus-covid-19-di-situbondo-sebagian-besar-dari-klaster-masjid.html> accessed 24 June 2020.

Amin S, 'Peran Masjid di Tengah Wabah Corona' (detiknews) <https://news.detik. com/kolom/d-4955153/peran-masjid-di-tengah-wabah-corona> accessed 18 June 2020.

Arab Saudi Tutup Masjidil Haram Dan Masjid Nabawi Selama Ramadan Dunia Tempo.Co' <https://dunia.tempo.co/read/1333753/arab-sauditutup-masjidil-haram-dan-masjid-nabawi-selama-ramadan $>$ accessed 30 September 2021.

detikcom T, 'Kapan Sebenarnya Corona Pertama Kali Masuk RI?' (detiknews) 
<https://news.detik.com/berita/d-4991485/ kapan-sebenarnya-coronapertama-kali-masuk-ri> accessed 17 June 2020.

El Muhtaj M, 'OPINI: Covid-19 dan Kedaruratan Kesehatan Nasional dalam Perspektif HAM' (kumparan) <https://kumparan.com/sumutnews/opinicovid-19-dan-kedaruratan-kesehatan-nasional-dalam-perspektif-ham1t8ktLq6yUt> accessed 12 September 2021.

Liputan6.com, 'Imbauan Jokowi terkait Covid-19, dari Kerja dari Rumah hingga Ingatkan Social Distancing' (liputan6.com, 16 March 2020) <https://www. liputan6.com/news/read/4202629/imbauan-jokowi-terkait-covid-19-darikerja-dari-rumah-hingga-ingatkan-social-distancing> accessed 17 June 2020.

Media KC, 'WHO Umumkan Virus Corona sebagai Pandemi Global Halaman all' (KOMPAS.com) <https://www.kompas.com/global/ $\mathrm{read} / 2020 / 03 / 12 / 001124570 /$ who-umumkan-virus-corona-sebagaipandemi-global> accessed 16 June 2020.

Okezone, 'Pro Kontra Larangan Sholat Jum'at di Tengah Wabah Corona : Okezone Tren' (https://www.okezone.com/, 19 March 2020) <https://www.okezone. com/tren/read/2020/03/19/620/2185963/pro-kontra-larangan-sholatjum-at-di-tengah-wabah-corona> accessed 18 June 2020.

Pertana PR, 'Ada 700-an Masjid di Bantul Gelar Jumatan Berjemaah Saat PPKM Darurat' (detiknews) <https://news.detik.com/berita-jawatengah/d-5646051/ada-700-an-masjid-di-bantul-gelar-jumatan-berjemaahsaat-ppkm-darurat> accessed 2 August 2021.

Wiratraman HP, 'Perlindungan HAM Dalam Kehidupan' < https://www.jawapos. com/opini/01/04/2020/perlindungan-ham-dalam-kehidupan/ $>$ accessed 12 September 2021.

\section{Perundang-undangan}

Undang-Undang Dasar Negara Republik Indonesia Tahun 1945.

Undang-Undang Nomor 12 Tahun 2005 tentang Pengesahan International Convenant on Civil and Political Rights (Kovenan Internasional tentang HakHak Sipil dan Politik).

Undang-Undang Nomor 24 Tahun 2007 tentang Penanggulangan Bencana.

Undang-Undang Nomor 6 Tahun 2018 tentang Kekarantinaan Kesehatan.

Peraturan Pemerintah Nomor 21 Tahun 2020 tentang Pembatasan Sosial Berskala 
Adam Muhshi: Pembatasan Kebebasan Beragama...

Besar dalam Rangka Percepatan Penanganan Corona Virus Disease 2019 (Covid-19).

Keputusan Presiden Nomor 11 Tahun 2020 tentang Penetapan Kedaruratan Kesehatan Masyarakat Corona Virus Disease 2019 (Covid-19).

Instruksi Menteri Dalam Negeri Nomor 15 Tahun 2021 tentang Pemberlakuan Pembatasan Kegiatan Masyarakat Darurat Corona Virus Disease 2019 di Wilayah Jawa dan Bali.

Instruksi Menteri Dalam Negeri Nomor 19 Tahun 2021 tentang Perubahan Ketiga Instruksi Menteri Dalam Negeri Nomor 15 Tahun 2021.

How to cite: Adam Muhshi dan Radian Salman, 'Pembatasan Kebebasan Beragama dalam Darurat Kesehatan Virus Korona di Indonesia: Perspektif HAM dan Islam' (2021) Vol. 4 No. 3 Media Iuris. 